\title{
Influence of Co-pyrolysis Conditions on Characteristics of Char Produced from Dried Sludge and Coal
}

\author{
Akira SUAmI ${ }^{*}{ }^{\dagger}$, Nobusuke KOBAYASHI ${ }^{* 2}$, and Yoshinori ITAYA ${ }^{* 2}$ \\ (Received December 28, 2017)
}

\author{
乾燥污泥と石炭の混合原料から生成されるチャー特性に熱分解条件が与える影響 \\ 須網＼cjkstart暁 ${ }^{*}{ }^{\dagger}$, 小林信介*2，板谷義紀*2
}

In recent years, co-firing and co-gasification using sludge and coal has been carried out for utilizing sewage sludge as new energy. In co-pyrolysis process on co-gasification and co-carbonization, clarifying the characteristics of char produced from sludge and coal is important. Because it is assumed that the reaction between char and pyrolysis gas will be occurred by blending both raw materials. So, we conducted co-pyrolysis experiments changed temperature, sample ratio and coal kind, and investigated the influence of co-pyrolysis conditions on char yield and surface area of co-char produced from sludge and coal by comparing with the characteristics of single char produced from a raw material. As a result, yield of co-char increased more than that of value added single chars, and pore surface area of co-char decreased more than that of value added single chars. In the case of using another kind coal in co-pyrolysis experiment, char yield, carbon ratio and heating value of co-char increased more than values added single chars. However, there is no difference of raman spectrum between co-char's and single char's. So, we revealed that char yield, pore surface area and element ratio of co-char produced from sludge and coal were not expressed by adding single char characteristics produced from a raw material. And mixing both materials during pyrolysis affected the characteristics of char.

\section{Key Words}

Sludge, Coal, Co-pyrolysis, Char

近年, 下水污泥を燃料として有効的に利用するため, 石炭との混焼が行われており，また混合ガス化が検討されている。 污泥と石炭の混合ガス化プロセスや混合炭化プロセスにおける熱分解過程では, 異なる原料から発生する熱分解ガスと チャーは相互に影響を与えるものと考えられるため, 混合原料から生成されるチャー性状を把握することは重要となる。そ のため, 乾燥污泥と石炭を一定割合で混合した原料を用いて, 熱分解温度や原料混合比, 石炭種を変化させた混合熱分 解実験を行い，混合原料から得られるチャーの収率や細孔比表面積などの性状と，それぞれ単独原料から得られるチャー の性状を比較することで, 混合熱分解条件の違いがチャー性状に与える影響を明らかにした。熱分解温度や原料混合比, 石炭種を変化させた実験結果から, 混合原料から生成されたチャーの収率は, 污泥チャーと石炭チャーそれぞれの比例配 分から計算したチャーの収率值に比べて増加し，混合原料から生成されたチャーの細孔比表面積は，比例配分から計算し たチャーの細孔比表面積に比べて減少した。混合原料中の石炭種を変化させた混合熱分解実験に掞いては, 混合原料か ら生成されたチャーの収率㧍よび炭素分, 発熱量は, 計算值に比べて増加した。一方, 各チャーのラマンスペクトルに大き な違いは見られなかった。そのため, 污泥と石炭の混合熱分解過程において生成されたチャーの収率や細孔比表面積, 元 素成分等には, 原料単独の熱分解から生成された各チャーによる加成性はなく, 原料の混合による熱分解はチャーの性状 に影響を与えていた。

キーワード

污泥, 石炭, 共熱分解, チャー

※ 1 Energy Engineering Research Laboratory, Central Research Institute of Electric Power Industry

2-6-1 Nagasaka, Yokosuka-shi, Kanagawa 240-0196, Japan

※2 Department of Mechanical Engineering, Faculty of Engineering, Gifu University 1-1 Yanagido, Gifu-shi, Gifu 501-1193, Japan

$\dagger$ Corresponding author: a_suami@gifu-u.ac.jp

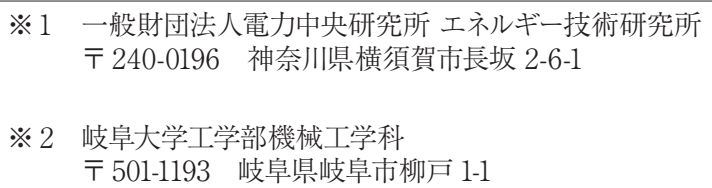

$※ 1$ 一般財団法人電力中央研究所 エネルギー技術研究所 干 240-0196 神奈川県横須賀市長坂 2-6-1

※2 岐阜大学工学部機械工学科 于 501-1193＼cjkstart岐阜県岐阜市柳戸 1-1 


\section{1. 緒 言}

下水污泥は低品位炭素資源としてエネルギー利用が進め られている。污泥は含水率が高く, エネルギーに利用する 場合は脱水や乾燥処理等 1)にエネルギーを必要とするが, 近年では堆肥化乾燥法 ${ }^{2)}$ などの生物発酵を利用した乾燥技 術の確立により低エネルギーでの乾燥処理が可能となってい る。そのため, エネルギー源としての污泥の利用が期待され ている、これまで污泥の利用法 3) 4)には, 高効率なエネルギー 利用として污泥のガス化発電 ${ }^{5)}$ が提案されている。しかしな がら, 污泥のガス化では, 污泥原料の調達量が少ないこと, 単位質量当りの発熱量が低いこと, 高灰分割合かつ低灰融 点であるため溶融スラグが大量に発生 ${ }^{6)}$ することから, 発電 設備において污泥原料のみによるエネルギー利用は困難で ある。その一方で石炭や木質系バイオマスは, ガス化発電 の原料として用いられており，両原料を用いた混焼や混合ガ ス化の実用化，もし〈は開発が進んでいる7）8。污泥と木質 系バイオマスは含有成分に大きな違いはあるものの，污泥 も有機物を含んで拈り，また下水道設備による運搬集約が 容易であることから，污泥もガス化原料として利用すること が可能で石炭との混合ガス化にも利用できることが考えられ る。また, 污泥に石炭を混合することで原料供給時の水分 および熱量の調整や灰溶融時の高融点化，污泥中揮発成分 の影響による石炭ガス化時の反応性の向上が期待されるな ど, 污泥あるいは石炭のみを利用したガス化にはない効果も 期待できる。

一般的にガス化プロセスにおいて，加熱された原料は熱 分解過程を経てチャーに変換される。異なる原料を用いた 混合ガス化においても, 両原料は熱分解過程を経るが, 原 料の熱分解温度や熱分解挙動が異なることから, 発生する 熱分解ガスやタールが原料やチャーの収率, 比表面積など の性状に影響を及ぼすことが考えられる。そのため，熱分 解過程において混合原料から生成されるチャー (以下, 混合 チャー）と，各原料単独の熱分解過程において生成される チャーの元素割合, 粒子形状, 細孔比表面積, 炭素構造な
どのチャー性状は異なる可能性が高く, そのチャー性状の 違いがチャーの反応性に影響を与えることが考えられる。ま た, チャーの細孔比表面積や炭素構造はガス化反応速度に 影響を与えており 9)，ガス化反応のシミュレーションにおいて も細孔比表面積は重要な因子となっている。これまで污泥 や石炭それぞれの熱分解挙動 10) 11) やチャー性状 12) 13) に関 する文献は多くあり,さらに木質系バイオマスと石炭の混合 熱分解挙動 ${ }^{14)}$ や混合ガス化時におけるタール改質効果 ${ }^{15)}$, ガス生成挙動 ${ }^{16)}$ についての知見も報告されている。しかしな がら, 污泥と石炭の混合ガス化時に扔ける熱分解過程で生 成されたチャーの収率や表面積などの性状に関する報告は 少なく, 熱分解温度や原料混合比などの条件の違いが混合 チャーの性状に与える影響について検討した報告も極めて少 ない。そのため, 前報 17) では熱分解温度 $1173 \mathrm{~K}$ の窒素流 通雲囲気下で, 一定割合で乾燥污泥と石炭を混合した原料 を用いて熱分解実験を行い, 得られた混合チャーの収率や 比表面積, 水蒸気ガス化反応性は, 単独原料から得られた 各チャーの特性とは異なり, 污泥および石炭の混合熱分解 がチャー性状に影響を与えていることを明らかにした。しか しながら, 熱分解温度や原料割合, 石炭種などの条件が混 合チャーの収率や比表面積などのチャー性状に与える影響は まだ明らかにされていない。

そこで本研究では, 乾燥污泥と石炭の混合原料を用いて熱 分解時の温度および原料混合比を変化させるとともに, 異な る石炭種を用いて熱分解実験を行った。実験では得られた混 合チャーと単独チャーの収率, 細孔比表面積, 元素成分お よび炭素構造などの分析を行い, 熱分解温度, 原料混合比 および石炭種がチャー性状に与える影響について評価した。

\section{2. 実 験}

\section{1 実験装置および方法}

Fig. 1 に熱分解実験に用いた装置の概要を示す。実験装 置は前報 ${ }^{17)}$ と同様である。実験では, 窒素流通䨌囲気下に て乾燥污泥㧍よび石炭の単独原料の単独熱分解, 乾燥污泥

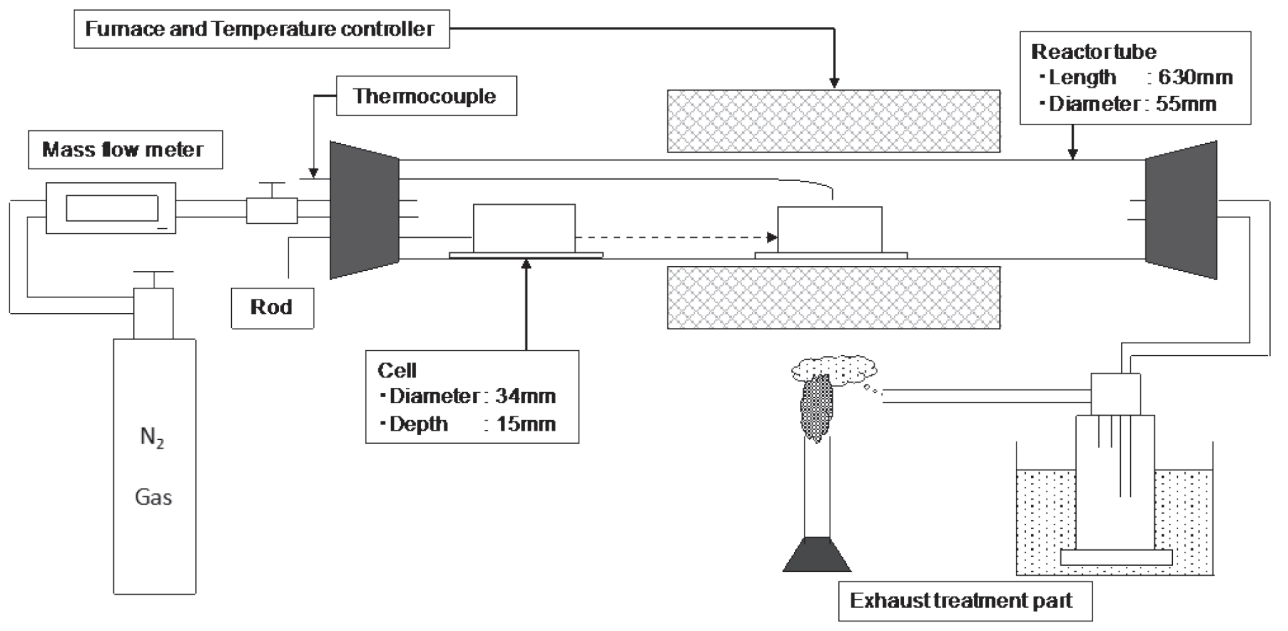

Fig. 1 Diagram for pyrolysis experiment 
と石炭の混合原料の混合熱分解を行った。実験開始前に原 料 4-5 g を加熱用セル内に充填し, 反応管内の非加熱部に 設置するとともに反応管内に窒素を $100 \mathrm{~mL} / \mathrm{min}$ 流通させな がら電気炉に覆われている反応管を昇温した。昇温時の温 度は加熱用七ル直上に設置した熱電対により任意の温度に 制御した。炉内温度が安定した後, 加熱用セルが反応管内 熱電対の真下に位置するように素早く押し出すことで, 原料 の急速加熱を行った。実験では乾燥污泥および 2 種の石炭 を用いた。石炭 A は中国安徽省で産出されたもので, 石炭 $\mathrm{B}$ はインドネシア産の燃料用石炭である。乾燥污泥と石炭 A は前報 ${ }^{17)}$ で用いた原料と同じである。Table 1 に各原料の工 業分析值，無水無灰ベースの元素分析值を示す。乾燥污泥 は脱水した下水污泥に堆肥化乾燥処理 ${ }^{18)}$ を施したものであ り，灰分拉よび揮発成分割合が高く，固定炭素が少ない。 石炭 $\mathrm{A}$ 抢よび $\mathrm{B}$ は，H/C および $\mathrm{O} / \mathrm{C}$ の值から亜瀝青炭の 性状に近く，燃料比と灰分量は異なっていた。実験前には 原料を乾燥機にて加熱温度 $380 \mathrm{~K}$ で乾燥させた。混合原料 には乾燥させた各原料を用いた。

本研究では, 熱分解温度および原料混合比, 石炭種の 違いによるチャー性状への影響を把握するため, 実験は以 下の 3 条件で行った。各原料の混合条件および熱分解条件 をTable 2 にまとめて示す。条件1では熱分解温度の影響を 把握するため, 乾燥污泥と石炭 A を石炭割合 20 mass\% で 混合したものを実験原料とし，熱分解温度を773-1173 K に 変化させた。その時の熱分解時間は $30 \mathrm{~min}$ 一定とした。条 件 2 では原料混合比の影響を把握するため, 熱分解温度 を $773 \mathrm{~K}$, 熱分解時間を $30 \mathrm{~min}$ 一定とし, 混合原料中の石 炭 Aの割合を 0-50 mass\% で変化させた。条件 3 では石炭 種の影響を把握するため, 混合原料に乾燥污泥と石炭 $\mathrm{B}$ を 用いた。混合原料の混合比は，熱分解により得られる污泥 チャーと石炭チャーの重量比が 1：1になるように, 熱分解 前の混合原料中の乾燥污泥と石炭の重量比を $1.09: 1$ に調 整した。その時の混合原料中の石炭割合は 48 mass\%である。 条件 3 では，条件 1,2 と同様な実験結果の傾向が得られる のか検討するだけでなく，前報 17) の実験結果とも比較検討 するため，前報 ${ }^{17)}$ と同じ熱分解温度 $1173 \mathrm{~K}$, 熱分解時間
$60 \min$ とした。

本実験では, 乾燥污泥および石炭 $\mathrm{A}$, 石炭 $\mathrm{B}$ の単独原 料の熱分解から得られるチャーを，それぞれ污泥チャーお よび石炭チャー A，石炭チャーB と呼ぶ。また，乾燥污泥 と石炭 Aの混合原料から得られるチャーを混合チャー A, 乾燥污泥と石炭 $\mathrm{B}$ の混合原料から得られるチャーを混合 チャーB と呼ぶ。

\section{2 評価方法}

異なる実験条件で得られたチャーは，チャー収率を測定 するとともに, チャーの細孔比表面積, 元素成分, 炭素構 造および表面観察を行った。チャー収率の算出は, 式 (1) より求めた。

$$
\text { Yield of char }=\frac{W_{\mathrm{a}}}{W_{\mathrm{b}}}
$$

ここで, $W_{a}$ は乾燥基準の熱分解後試料重量, $W_{b}$ は乾燥基準 の熱分解前試料重量である。チャーの細孔比表面積は, 全 自動ガス吸着量測定装置 (AUTOSORB-1, Quantachrome) を用いて窒素ガス吸着により，BJH 法によるチャーの細孔分 布を測定した。細孔比表面積は細孔分布の積算から求めた。 組成分析では, JIS M 8812-8813 に準じた工業分析，元素 分析を行った。元素分析には元素分析装置 (Vario EL cube, Elementar）を使用し，炭素，水素，窒素拈よび硫黄成分の 測定を行った。酸素成分については全体重量の差分により 算出した。チャーの炭素構造は, 顕微鏡を備えたレーザー ラマン分光器 (レーザーラマン分光光度計, 日本分光製) を 用い, ラマンスペクトル分析を行った。また, SEM（HITACHI S-4300，日立ハイテクノロジーズ製）を用いてチャー表面の観 察も行った。

\section{3. 結果および考察}

\section{1 熱分解温度が混合チャー収率および細孔比表面積に与 える影響}

Fig. 2 に条件1で得られた混合チャーAの収率を示す。 Fig. 2 には単独原料の熱分解実験で得られた污泥チャーと 石炭チャーAの収率も示す。また, 混合チャー収率との比

Table 1 Analysis of experimental sample

\begin{tabular}{|c|c|c|c|c|c|c|c|c|c|c|c|c|c|}
\hline & \multicolumn{4}{|c|}{ Proximate analysis ${ }^{* 1}[$ mass \%] } & \multirow[b]{2}{*}{$\begin{array}{c}\text { Fuel } \\
\text { ratio [-] }\end{array}$} & \multicolumn{5}{|c|}{ Ultimate analysis"2 [mass \%] } & \multirow[b]{2}{*}{$\mathrm{H} / \mathrm{C}$} & \multirow[b]{2}{*}{$\mathrm{O} / \mathrm{C}$} & \multirow[b]{2}{*}{$\begin{array}{c}\mathrm{LHV}^{* 2} \\
{[\mathrm{MJ} / \mathrm{kg}]}\end{array}$} \\
\hline & $\begin{array}{l}\text { Moisture } \\
\text { (w. b.) }\end{array}$ & $\begin{array}{l}\text { Volatile } \\
\text { matter }\end{array}$ & $\begin{array}{l}\text { Fixed } \\
\text { carbon }\end{array}$ & Ash & & $\mathrm{C}$ & $\mathrm{H}$ & $\mathrm{N}$ & S & $\mathrm{O}$ & & & \\
\hline Dried sludge & 18.82 & 45.29 & 14.23 & 40.48 & 0.31 & 45.04 & 6.39 & 6.89 & 2.86 & 38.82 & 1.51 & 0.63 & 21.45 \\
\hline Coal A & 1.42 & 31.02 & 51.97 & 17.01 & 1.68 & 81.37 & 5.16 & 1.39 & 0.41 & 11.68 & 0.76 & 0.11 & 34.30 \\
\hline Coal B & 3.35 & 37.34 & 49.76 & 12.89 & 1.33 & 85.59 & 6.46 & 1.64 & 0.73 & 5.58 & 0.91 & 0.05 & 33.45 \\
\hline
\end{tabular}

${ }^{{ }_{1}}$ dry base, ${ }^{* 2}$ dry ash free

Table 2 Experimental conditions of co-pyrolysis

\begin{tabular}{ccccc}
\hline Experiment No. & Coal & Mixing coal ratio [mass \%] & Temperature [K] & Duration [min] \\
\hline 1 & Coal A & 20 & $773-1173$ & 30 \\
\hline 2 & Coal A & $0-50$ & 773 & 30 \\
\hline 3 & Coal B & 48 & 1173 & 60 \\
\hline
\end{tabular}




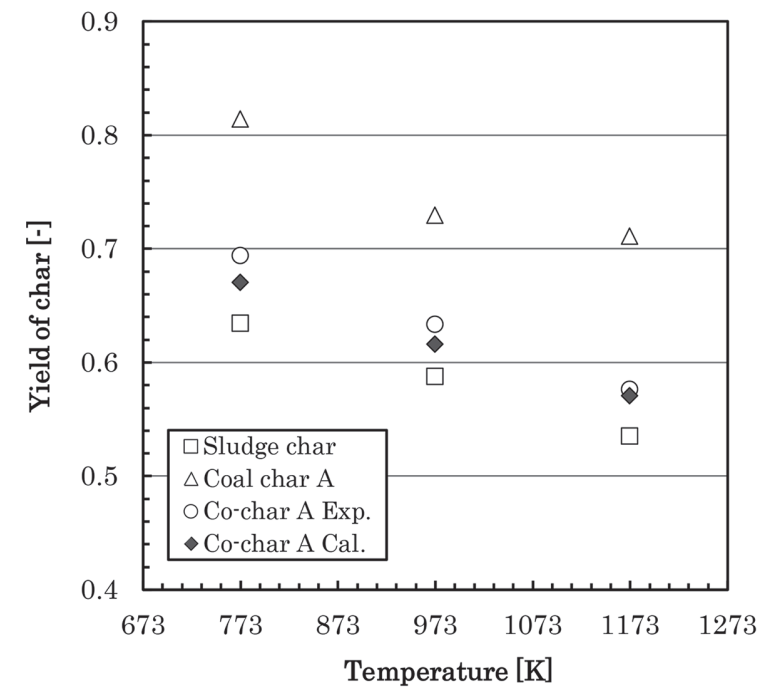

Fig. 2 Yield of chars manufactured in experiment No. 1

較のため, 混合原料の比例配分で污泥チャー収率と石炭 チャー収率を相加平均した計算值も示す。計算值は, 式 (2) より算出した。

Calculation yield $=C_{s} Y_{s}+C_{c} Y_{c}$

ここで $C_{s}$ は混合原料中の乾燥污泥の割合, $Y_{s}$ は污泥チャー 収率, $C_{c}$ は混合原料中の石炭の割合, $Y_{c}$ は石炭チャー収率で ある。污泥チャーの収率は熱分解温度の上昇とともに低下 した。石炭チャーの収率も熱分解温度の上昇とともに低下し たが，973-1173 K における収率の差は773-973 K における 収率の差に比べて小さかった。混合チャーの収率は熱分解 温度の上昇とともに低下した。混合原料の熱分解挙動では, 混合原料には石炭が含まれているにも関わらず, 石炭の熱分 解挙動とは異なり 973-1173 K においても熱分解が進んでい た。その原因として，973-1173 K においても熱分解が進ん でいた乾燥污泥が, 混合原料の熱分解に影響を与えたこと が考えられる。混合チャーの実験值と計算值を比較した場 合, 各温度において混合チャー収率は計算值より高い収率 となった。また, 熱分解温度が高くなるほど混合チャー収 率と計算值の差は小さくなる傾向が見られた。

Fig. 3 に条件1で得られた混合チャーAの細孔比表面積 を示す。また比較のため, 混合原料の比例配分で各チャー の細孔比表面積を相加平均した計算值も示す。計算值は, 式（3）より算出した。

Calculation specific surface area $=\frac{S_{s} W_{s} Y_{s}+S_{c} W_{c} Y_{c}}{\left(W_{s} Y_{s}+W_{c} Y_{c}\right)}$

ここで $S_{s}$ は污泥チャーの細孔比表面積, $W_{s}$ は混合原料中の 単位質量当たりの乾燥污泥重量, $Y_{s}$ は污泥チャー収率, $S_{c}$ は 石炭チャーの細孔比表面積, $W_{c}$ は混合原料中の単位質量当 たりの石炭重量, $Y_{c}$ は石炭チャー収率である。混合チャーの 細孔比表面積は熱分解温度の上昇とともに増加した。計算 值と比較した場合, 混合チャーの細孔比表面積は 773-973 K において計算值より低い值となっていた。しかし，1173 K において混合チャーの細孔比表面積は, 計算值より高い值

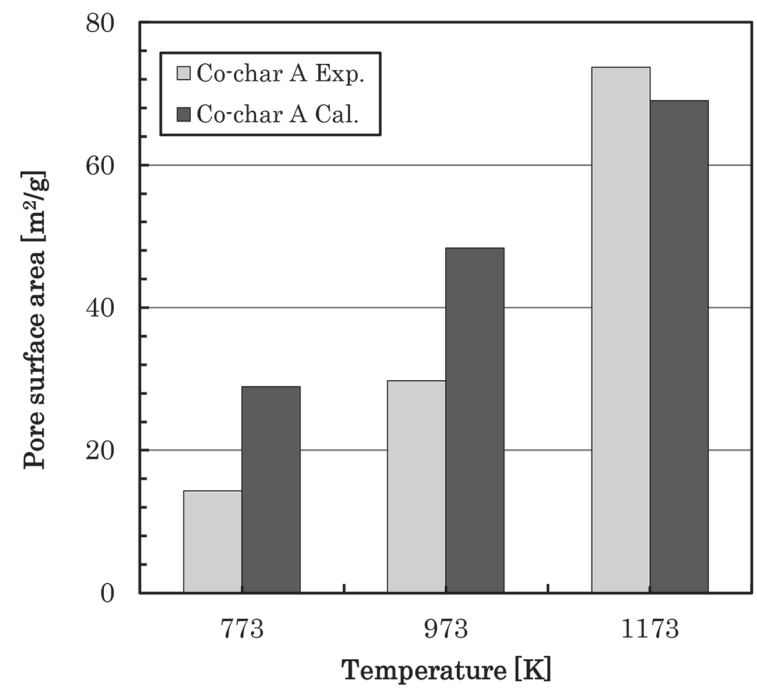

Fig. 3 Pore surface area of co-chars manufactured in experiment No. 1

となっていた。

$773 \mathrm{~K}$ と $973 \mathrm{~K}$ で混合チャーの収率および細孔比表面積 が計算值より低い原因として, 混合原料の熱分解過程にお いて, 乾燥污泥は石炭に比べて低温から熱分解が進み細孔 を有するチャーとなる。一方で, 比較的高温で熱分解が進む 石炭から放出される熱分解ガス中のベンゼンやテトラリンな どの芳香族炭化水素化合物を主成分 ${ }^{19)}$ とした凝縮性ガス成 分が污泥チャーの細孔に粒子内タール20) として蓄積し, 本 来有しているはずの污泥チャーの細孔を閉塞させたことが考 えられる。そのため, 粒子内タールの影響により混合チャー 収率は計算值に比べて高くなり, 混合チャーの細孔比表面 積は計算值に比べて低下したものと考えられる。また, 熱分 解時の温度が高いほど, 石炭から放出される熱分解ガスの 拡散速度が生成速度より速くなり, 污泥チャーの細孔に粒 子内タールとして蓄積する割合が少なくなるため, 混合チャー 収率と計算值の差が小さくなったものと考えられる。一方, Fig. 3 の $1173 \mathrm{~K}$ に扔ける混合チャーの細孔比表面積が計算 值より高い值となった原因としては, 乾燥污泥の熱分解によ り生成した水蒸気や二酸化炭素が一部ガス化剤としてチャー と反応し, チャーの細孔を発達させたことが考えられる。

\section{2 原料混合比が混合チャー収率および細孔比表面積に与 える影響}

Fig. 4 に条件 2 で得られた混合チャーAの収率を示す。 また, 混合チャー収率と比較するため, 混合原料の比例配 分で污泥チャー収率と石炭チャー収率を相加平均した計算 值も示す。計算值は, 式 (2) より算出した。混合チャーの 収率は石炭割合の増加とともに増加した。Fig. 2 の $773 \mathrm{~K} に$ おいて, 石炭チャーAの収率は污泥チャーの収率より高く, 混合原料を熱分解した場合に抏いても石炭チャーの重量が 污泥チャーより多くなるため, 混合原料中の石炭割合を増や すことで混合チャー収率も増加した。混合割合を変化させた 


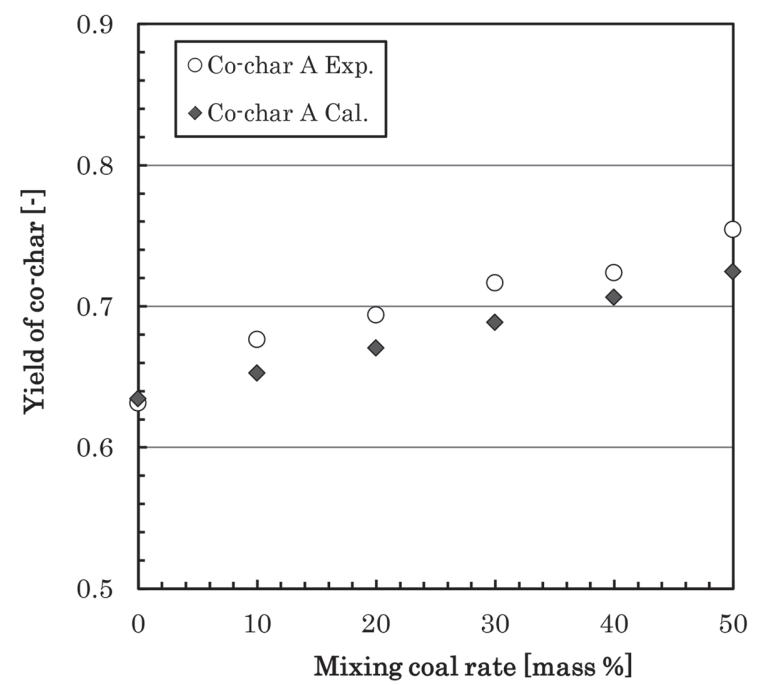

Fig. 4 Yield of chars manufactured in experiment No. 2

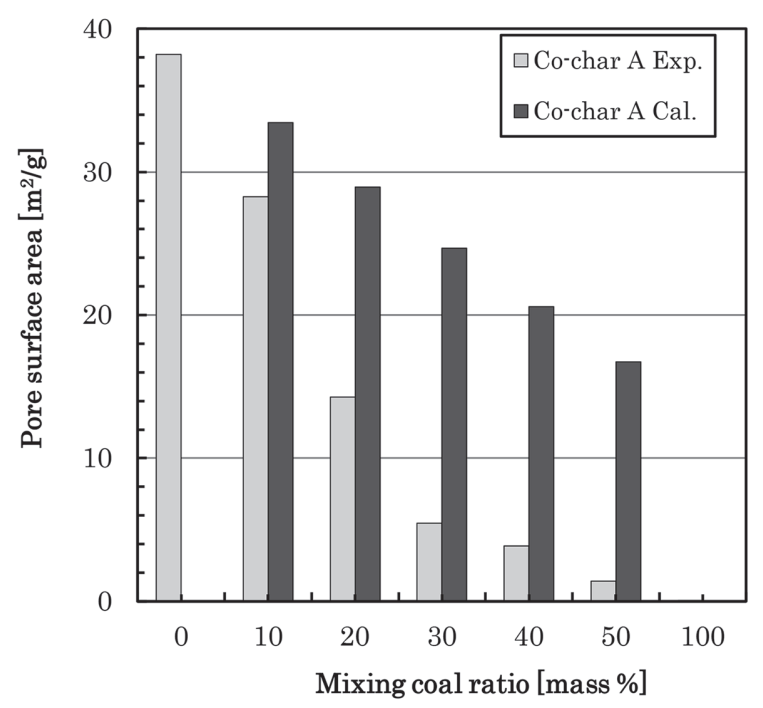

Fig. 5 Pore surface area of co-chars manufactured in experiment No. 2

場合においても，熱分解温度を変化させた場合と同様に混 合チャーの収率は，計算值に比べて高い值となっていた。

Fig. 5 に条件 2 で得られた混合チャーAの細孔比表面積 を示す。また比較のため, 混合原料の比例配分で污泥チャー と石炭チャーの細孔比表面積を相加平均した計算值も示す。 計算值は，式 (3) より算出した。混合チャーの細孔比表面 積は石炭混合割合が増加するにつれて低下し, どの石炭割 合においても混合チャーの細孔比表面積は，計算值に比心゙ て低い值となった。また，石炭割合が増加するにつれて混 合チャーの細孔比表面積と計算值の差は増加していた。

条件 1 の熱分解温度を変化させた実験結果と同様に, 条 件 2 の原料混合比を変化させた実験においても，混合チャー の収率と細孔比表面積は計算值と一致せず，混合原料の熱 分解において単独原料の熱分解から得られた各チャーの加 成性は見られなかった。この原因として，污泥チャーの細孔
内で粒子内タール 20) が蓄積したことにより混合チャー収率 が計算值に比べて増加したことが考えられる。また石炭割合 が大きい方がタールの発生量が多く, 細孔への蓄積量も多 くなったため, 混合チャーの細孔比表面積は計算值に比べ て減少し, 石炭の混合割合が増加するにつれて細孔比表面 積と計算值との差が大きくなったものと考えられる。一方で, Fig. 3 からでは石炭割合の増加に対して混合チャー収率と計 算值の差が増加もしくは低下する傾向は見られず，本実験で は石炭割合に対する混合チャー収率と計算值との差につい て, 明確な相関は得られなかった。

\section{3 燃料用石炭を用いた混合熱分解実験結果}

Fig. 6 に污泥チャー 17) および石炭 B の熱分解から得られ た石炭チャーB, 条件 3 にて得られた混合チャーBの収率 を示す。また比較のため, 污泥チャーの収率と石炭チャーB の収率を相加平均した計算值も示す。計算值は, 式 (2) よ り算出した。污泥チャーは前報 ${ }^{17)}$ の結果であり, チャー収 率は 0.56 , チャー中の灰分割合は $72 \%$ あるる。污泥チャー 収率の標準偏差 ${ }^{17)}$ は $3.1 \times 10^{-3}$, 石炭チャーB $10^{-3}$, 混合チャー B は $3.5 \times 10^{-3}$ であり各チャー収率のバラ ツキは小さいものであった。石炭チャーB の収率は 0.61 と なり, 含有灰分割合は 19.0 \% となった。混合チャーB の収 率は 0.60 となり, 含有灰分割合は $47 \%$ となった。混合チャー 収率と計算值を比較した場合, 計算值の収率は 0.59 であ り，混合チャー収率は計算值より 0.01 高い值となった。混 合チャー収率と計算值の差は極めてわずかであるが, 石炭 B を混合原料に用いた場合においても，計算值より増加してい る。そのため, 混合原料に用いる石炭種の違いにより混合 チャー収率へ与える影響の差は見られるものの, 混合熱分 解過程における原料の混合は, 混合チャーの収率に影響を 与えるものと考えられる。

Table 3 に污泥チャー ${ }^{17)}$, 石炭チャーB B およ゙混合チャー $\mathrm{B}$ の元素分析值および污泥チャーおよび石炭チャーB 中の

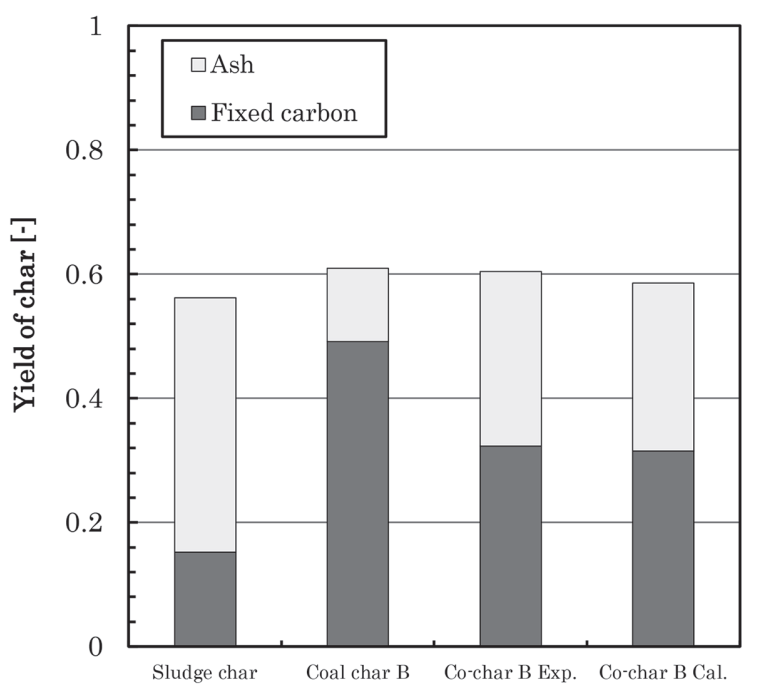

Fig. 6 Yield of chars manufactured in experiment No. 3 
Table 3 Ultimate analysis and heating value of chars (dry ash free)

\begin{tabular}{|c|c|c|c|c|c|c|c|c|}
\hline & \multicolumn{5}{|c|}{ Ultimate analysis [mass \%] } & & \multirow{2}{*}{$\begin{array}{c}\text { Energy yield } \\
{[-]}\end{array}$} & \multirow{2}{*}{$\begin{array}{c}\text { Pore surface } \\
\text { area }\left[\mathrm{m}^{2} / \mathrm{g}\right]\end{array}$} \\
\hline & $\mathrm{C}$ & $\mathrm{H}$ & $\mathrm{N}$ & $\mathrm{S}$ & $\mathrm{O}$ & LHV [MJ/kg] & & \\
\hline Sludge char & 84.79 & 1.55 & 3.51 & 8.83 & 1.32 & 33.73 & 1.57 & 82.90 \\
\hline Coal char B & 95.95 & 0.84 & 1.68 & 1.08 & 0.43 & 35.03 & 1.05 & 2.22 \\
\hline Co-char B & 94.40 & 0.73 & 2.19 & 2.18 & 0.50 & 39.78 & 1.45 & 12.00 \\
\hline Calculation & 93.15 & 1.02 & 2.14 & 3.03 & 0.66 & 34.38 & 1.25 & 42.56 \\
\hline
\end{tabular}

各成分を相加平均した計算値も示す。計算值は，式 (4)よ り算出した。

$$
\text { Calculation concentration }=\frac{E_{s i}+E_{c i}}{2}
$$

ここで $E_{s i}$ は污泥チャー中の各元素成分濃度, $E_{c i}$ は石炭 チャー B 中の各元素成分濃度である。 $i$ は炭素, 水素, 窒素, 硫黄の各元素である。また, Table 3 には各チャーの低位発 熱量とチャーの熱量収率も示す。熱量収率は, 式 (5)より算 出した。

$$
\text { Calorific value yield }=\frac{H_{c}}{H_{r}} \times Y_{c}
$$

ここで $H_{c}$ は各チャーの低位発熱量, $H_{r}$ は各原料の低位発熱 量, $Y_{c}$ は各チャーの収率である。污泥チャーは他のチャーに 比べて炭素分は少なく, 原料の乾燥污泥には窒素および硫 黄分が多く含まれていることから，污泥チャー中の窒素およ び硫黄分は多くなっていた。一方で污泥チャーの低位発熱 量は増加しており，熱分解とともに炭素分が増加したことに より熱量収率は 1.57 となった。石炭チャー B は炭素分が高 く，水素㧍よび酸素成分は数\%であった。石炭チャーB 中 の窒素および硫黄分は低いものの, 石炭原料から石炭チャー への窒素および硫黄分の残留率は窒素が 0.59 , 硫黄が 0.86 となり，石炭中の窒素㧍よび硫黄分は熱分解後も半分以上 がチャー中に残留していた。石炭原料に対して石炭チャーB の低位発熱量の増加は小さく, 熱分解後も石炭チャーに残 留する熱量収率の変化はあまり見られなかった。混合チャー B の炭素分は污泥チャーの炭素分に比べて高く, 石炭チャー B に比べて低い值となった。混合チャーと計算值の炭素分を 比較した場合, 混合チャーの炭素分は計算值に比べて高く なった。混合チャーの炭素分が増加した原因として, 污泥 チャーの細孔へ蓄積した粒子内タール20)の炭素分による影 響が考えられる。一方, 混合チャーB 中の硫黄分は計算值 に比べ低くなった。污泥中の硫黄は污泥灰中のカルシウムと 結合し，硫化カルシウムとしてチャー中に残留する ${ }^{21)}$ と考え られるが，混合チャーでは乾燥污泥に石炭を混合したことに より, 污泥灰分の割合が低下し, 揮発する硫黄分が増加し たため，混合チャー中の硫黄分が計算值に比べて低下した ものと考えられる。また混合チャーB の発熱量は計算值より 高くなっており，これはタールの蓄積により混合チャーの炭 素分が増加していることが原因と考えられる。

Fig. 7 に污泥チャー ${ }^{17)}$ ，石炭チャーB，混合チャーBの 細孔分布を示す。また比較のため, 污泥チャーおよび石炭 チャーの細孔分布を重量ベース 1：1で加算した值も示す。 污泥チャーは細孔径 20-100 nm の範囲におけるメソポア孔

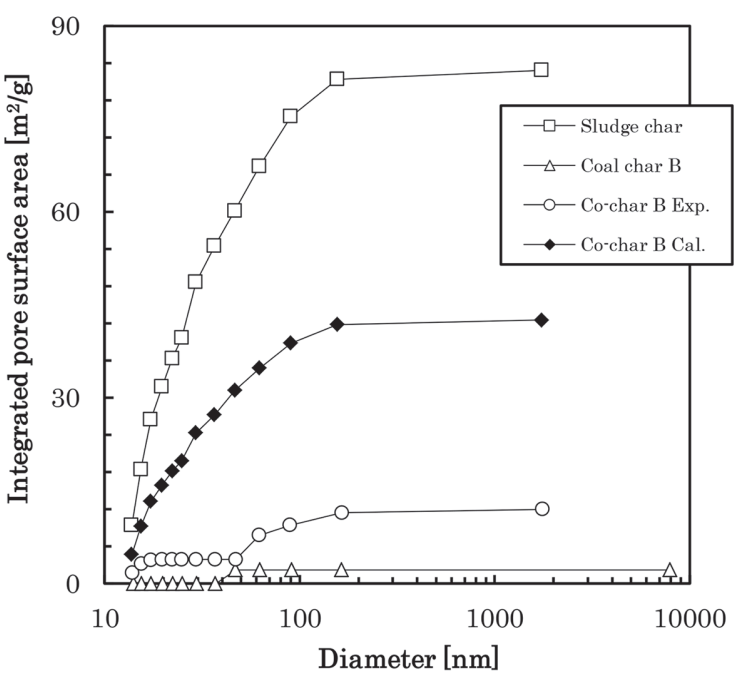

Fig. 7 Pore distribution of chars manufactured in experiment No. 3

が発達しており, 積算した細孔比表面積は $82.90 \mathrm{~m}^{2} / \mathrm{g}$ となっ た。石炭チャーBの積算細孔比表面積は $2.22 \mathrm{~m}^{2} / \mathrm{g}$ とな り，細孔分布からは細孔の発達はほとんど見られなかった。 一般的に石炭の熱分解時には揮発分の分解や細孔構造の 発達により表面積が増加する傾向 ${ }^{22)}$ にあるものの, 本研究 で用いた石炭チャーBの細孔比表面積は小さかった。混合 チャーB は細孔径 60-100 nm の範囲に細孔が分布し，積算 細孔比表面積は $12.00 \mathrm{~m}^{2} / \mathrm{g}$ となった。この值は污泥チャー と石炭チャーB の細孔比表面積を同重量比で加算した場合 の計算值 $42.56 \mathrm{~m}^{2} / \mathrm{g}$ より大幅に小さく, 石炭 B を混合原料 に用いた場合, 混合チャーB の細孔比表面積は計算值に比 ベて低下した。混合チャーB の細孔分布と計算による細孔 分布を比較した場合, 混合チャーの細孔径 20-50 nm の範囲 では，比表面積の増加はほとんど見られなかった。細孔径 20-100 nmの範囲において污泥チャーの細孔は増加し, 石 炭チャーは増加していないことから, 混合チャーの細孔分布 は石炭混合の影響により，混合原料中の污泥チャーの細孔 が閉塞したことが考えられる。そのため，乾燥污泥と石炭の 混合ガス化時の熱分解過程では，単独熱分解から得られる チャーを加算した值に比べて混合チャーの細孔比表面積が 低下するため，ガス化時におけるガス化速度やガス化挙動な どのガス化反応性に影響を与えること 23) 24) が考えられる。

Fig. 8 に污泥チャー ${ }^{17)}$ ，石炭チャーB，混合チャーBの ラマンスペクトルを示す。各チャーとも $1360 \mathrm{~cm}^{-1}$ と $1600 \mathrm{~cm}^{-1}$ 付近の D バンドと $\mathrm{G}$ バンドにブロードなピークが見られた。 各チャーの $\mathrm{R}$ 值 $\left(\mathrm{I}_{\mathrm{D}} / \mathrm{I}_{\mathrm{G}}\right)$ は污泥チャーが 0.89 ，石炭チャー 


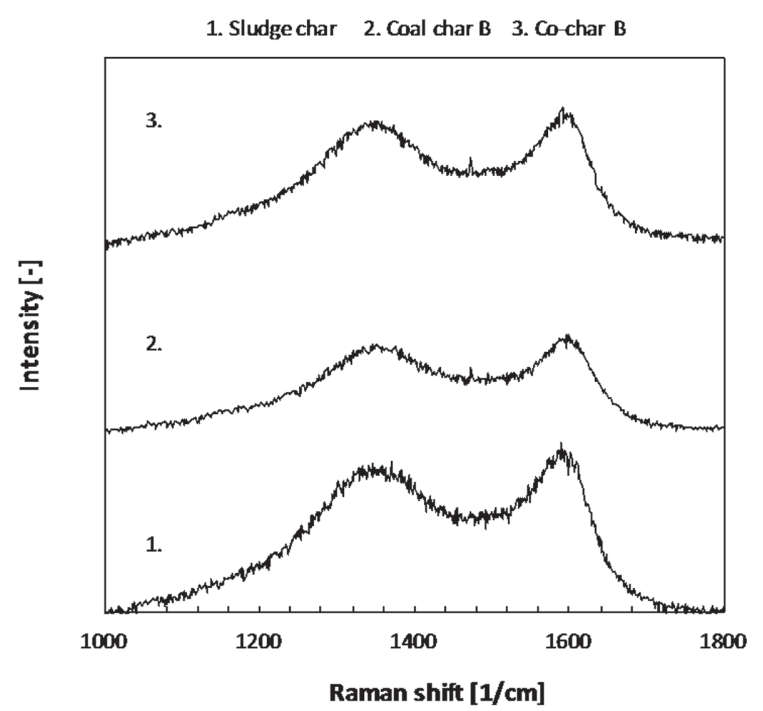

Fig. 8 Raman spectrum of chars manufactured in experiment No. 3

B が 0.90, 混合チャーB が 0.91 となり, 各チャーのスペク トル形状は類似していた。前報 ${ }^{17)}$ に記載した石炭 A と混合 原料を $1173 \mathrm{~K}$ で熱分解して得られた石炭チャーおよび混合 チャーの R 值は，ともに 1.02 でありほぼ一致していた。本 実験においても石炭チャーB 抄よび混合チャーBの R 值は ほぼ一致した。そのため, 污泥チャーおよび石炭チャー, 混 合チャーのラマンスペクトルの測定結果により得られた $\mathrm{R}$ 值 を比較した限りでは，熱分解時における原料の混合が炭素 構造へ与える影響は少ないものと考えられる。

Fig. 9 (a) - (c)に污泥チャー ${ }^{17)}$, 石炭チャーB, 混合チャー B の SEM 画像をそれぞれ示す。各画像は同倍率で撮影し た。污泥チャーの表面形状は粗く, 粒径は 5-30 $\mu \mathrm{m}$ で球状 の粒子が多く観測された。石炭チャーBの表面は滑らかな 部分が多く，大きな空洞が見られるものの，平らな面であり 細孔や凹凸などはあまり観測されなかった。混合チャーBの 表面では，滑らかな粒子面と複数の粗い表面の小さな粒子 が観測された。污泥チャーと石炭チャーB の SEM 画像より, 前者は石炭チャー由来であり, 後者は污泥チャー由来のも のと考えられ，各粒子の凝集状態が観測された。前報 ${ }^{17)} に$ おいても混合チャー表面の SEM 画像には污泥チャーと石炭 チャーの凝集状態が観測されており，異なる石炭種を用いた 場合でも同様の結果が得られた。

各チャーの細孔比表面積, ラマンスペクトル, SEM 画像 から, 混合原料の熱分解過程ではラマンスペクトル測定によ るチャーの炭素構造の変化は見られず，表面形状や表面積 などの表面特性の変化が見られた。これらの原因の一つに は污泥チャーの細孔内への粒子内タールの蓄積による影響 が考えられるが，粒子内タールとして蓄積した成分および機 構などの詳細については今後さらなる検討が必要とされる。

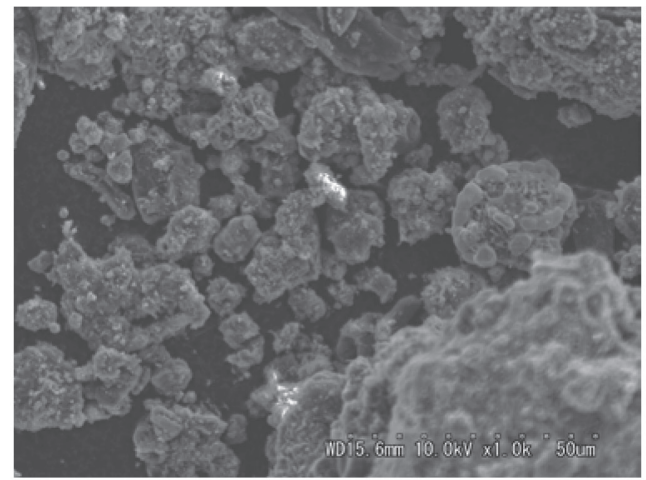

(a) Sludge char $^{17)}$

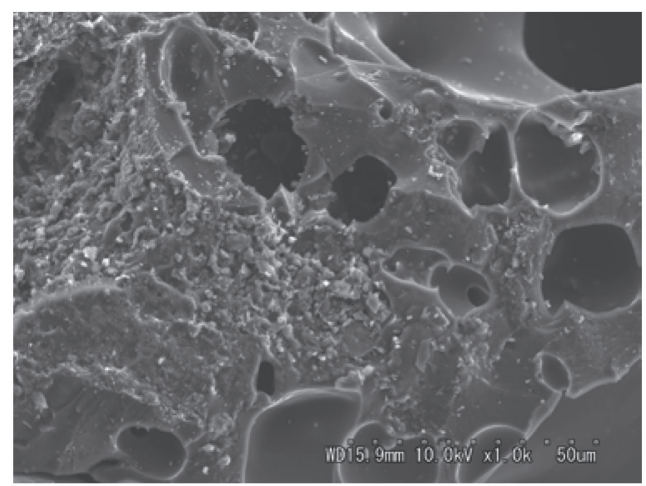

(b) Coal char B

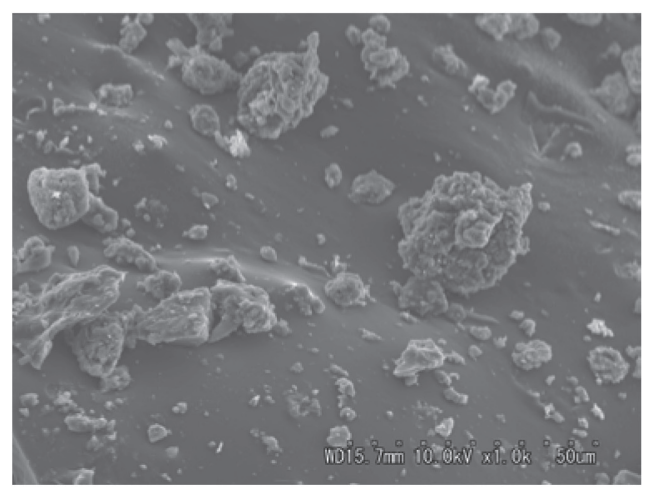

(c) Co-char B

Fig. 9 SEM image of chars manufactured in experiment No. 3

\section{4. 結 言}

乾燥污泥と石炭の混合熱分解過程において, 熱分解温度 および原料混合比，石炭種が混合チャーの収率や細孔表面 積，元素成分，炭素構造などの特性に与える影響を明らか にするため, 熱分解温度および原料混合比, 混合原料中の 石炭種を変化させた混合熱分解実験を行い，以下の知見を 得た。

1）熱分解温度および原料混合比を変化させた混合熱分解 において, 単独熱分解により得られる污泥チャーと石炭 チャーの比例配分で相加平均した值に比べて, 混合原料 から得られる混合チャーの収率は増加し, 細孔比表面積 は減少した。

2) 異なる炭種を混合原料に用いた場合の混合熱分解におい 
ても, 混合チャーの収率および炭素分, 発熱量は計算值 に比べて増加し, 混合チャーの細孔比表面積は計算值に 比べて減少した。一方で, 污泥チャーおよび石炭チャー, 混合チャーのラマンスペクトルの形状や $\mathrm{R}$ 值に違いは見ら れなかった。

3）乾燥污泥と石炭の混合原料を用いた混合熱分解実験にお いて, 混合チャー収率や細孔比表面積には，単独原料の 熱分解から得られた各チャーの加成性が見られなかった。 この原因として污泥チャーの細孔内での粒子内タールの蓄 積による影響が考えられる。

\section{文 献: References}

1) Yoshida, T., Sludge Treatment and Recycle Technology (in Japanese), N T S Co., Ltd. : 吉田隆, 污泥の処理とリ サイクル技術，株式会社エヌ・ティー・エス，(2010)

2) Kobayashi, N.; Hamabe, H.; Li, Y.; Itaya, Y.; Ueno, K.; Ninomiya, Y., Kagaku Kougaku Ronbunsyu, 40, 1-6 (2014) : 小林信介, 浜辺久, 李延亮, 板谷義紀, 上野薰, 二宮善彦, 化学工学論文集, 40, 1-6 (2014)

3) Oshita, K.; Takaoka, M.; Mizuno, T., Doboku Gakkai Ronbunsyu G, 68, 317-324 (2012): 大下和徹, 高岡昌輝, 水野孝昭，土木学会論文集 G (環境)，68, 317-324 (2012)

4) Shimura, S.; Kabuto, T.; Kitabayashi, M.; Shimizu, K., Denkiseikou, 78, 73-78 (2007) : 志村進, 甲忠敏, 北林誠, 清水健司，電気製鋼，78，73-78 (2007)

5) Haneda, T.; Taketani, R.; Amano, T.; Tatsumi, K.; Hayashi, K.; Saiga, A., Haikibutu Shigen Junkan Gakkai Ronbunshi, 22, 93-100 (2011): 羽田貴英, 武谷亮, 天野寿二, 巽圭司, 林一毅, 斉賀亮宏, 廃衰物資源循環学会論文誌, 22, 93-100 (2011)

6) Zhang, Q.; Liu, H.; Qian, Y.; Xu, M.; Li, W.; Xu, J., Fuel Processing Tech., 110, 218-226 (2013)

7) Kajitani, S.; Zhang, Y.; Umemoto, S.; Ashizawa, M.; Hara, S., Energy Fuels, 24, 145-151 (2010)

8) Howaniec, N.; Smolinski, A., Energy, 118, 18-23 (2017)

9) Adschiri, T.; Furusawa, T., Fuel, 65, 927-931 (1986)

10) Hu, E.; Zeng, X.; Ma D.; Wang, F.; Li, Y.; Guo, E.; Fu, X.,
Fuel, 200, 186-192 (2017)

11) Agarwal, M.; Tardio, J.; Mohan, V., Bioresource Tech., 178, 70-75 (2015)

12) Howaniec, N., Fuel, 172, 118-123 (2016)

13) Alvarez, J.; Lopez, G.; Amutio, M.; Bilbao, J.; Olazar, M., Process Safety and Environmental Protection, 103, 76-86 (2016)

14) Li, S.; Chen, X.; Liu, A.; Wang, L.; Yu, G., Bioresource Tech., 179, 414-420 (2015)

15) Tursun, Y.; Xu, S.; Wang, G.; Wang, C.; Xiao, Y., Journal of Analytical and Applied Pyrolysis, 111, 191-199 (2015)

16) Emami, L.; Faisal, M.; Ashri, W.; Harun, M., Biomass \& Bioenergy, 57, 249-263 (2013)

17) Suami, A.; Kobayashi, N.; Itaya, Y., J. Jpn, Inst. Energy, 96, 8-15 (2017): 須網暁，小林信介，板谷義紀，日工不誌, 96, 8-15 (2017)

18) Itaya, Y.; Kobayashi, N.; Li, L.; Suami, A.; Sawai, M.; Hamabe, H., Drying Technology, 33, 1029-1038 (2015)

19) Mae, K.; Miura, K.; Sakurada, K.; Hashimoto, K., J. Jpn, Inst. Energy, 72, 787-794 (1993) : 前一広, 三浦孝一, 桜田 清恭，橋本健治，日工市誌，72, 787-794 (1993)

20) Hayashi, J.; Ando, R.; Maezono, T.; Kusakabe, K.; Morooka, S., Nenryo Kyoukaishi, 69, 378-384 (1990) : 林潤 一郎, 安藤亮, 前園利樹, 草壁克己, 諸岡成治, 燃料協会誌, 69, 378-384 (1990)

21) Suami, A.; Kobayashi, N.; Hamabe, H.; Sawai, M.; Itaya, Y., Transactions of the JSME, 81, (2015), DOI: 10.1299/ transjsme.14-00439 (in Japanese) : 須網暁, 小林信介, 浜辺久, 澤井正和, 板谷義紀, 日本機械学会論文集, 81, (2015), DOI: 10.1299/transjsme.14-00439

22) Chen, Y.; Matsuda, H.; Hasatani, M., Kagaku Kougaku Ronbunsyu, 19, 672-676 (1993):陳勇, 松田仁樹, 架谷昌信, 化学工学論文集, 19, 672-676 (1993)

23) Chen, H.; Chen, X.; Qin, Y.; Wei, J.; Liu, H., Bioresource Tech., 228, 241-249 (2017)

24) Vyas, A.; Chellappa, T.; Goldfarb, J., Journal of Analytical and Applied Pyrolysis, 124, 79-88 (2017) 